\title{
Tectonic-Geophysical Mapping of Israel and the Eastern Mediterranean: Implications for Hydrocarbon Prospecting
}

\author{
Lev Eppelbaum ${ }^{1}$, Youri Katz ${ }^{2}$
}

${ }^{1}$ Department of Geophysics and Planetary Sciences, Raymond and Beverly Sackler Faculty of Exact Sciences, Tel Aviv University, Ramat Aviv, Israel; ${ }^{2}$ Paleontological Division of the Zoological Museum, Department of Zoology, Faculty of Life Sciences, Tel Aviv University, Ramat Aviv, Israel.

Email: levap@post.tau.ac.il

Received December $7^{\text {th }}, 2010$; revised December $27^{\text {th }}, 2010$; accepted January $17^{\text {th }}, 2011$.

\begin{abstract}
The eastern Mediterranean is a tectonically complex region evolving in the long term located in the midst of the progressive Afro-Eurasian collision. Despite years of investigation, its geological-geophysical structure is not completely known. At the same time, the recent discovery of large gas deposits has attracted the attention of many researchers to this region. For instance, the latest U. S. Geological Survey estimates using conventional assessment methodology suggest that there are on the order of 1.7 billion barrels of recoverable oil and more than 4 trillion $\mathrm{m}^{3}$ of recoverable gas in the Levant Basin [1]. This highlights the need for analysis of the paleogeographical conditions that can yield deep paleotectonic criteria for oil and gas discovery in this region. For this purpose, isopach maps of the Middle-Upper Jurassic and Lower Cretaceous were generated from detailed examinations of numerous well sections and the most significant outcroppings in the eastern Mediterranean. The maps confirm an earlier model of continental accretion [2]. In particular, abrupt changes in the trend and thickness of the Early Mesozoic formations coincide with the terrane boundaries. These compiled isopach maps also pinpoint significant distinctions between the Arabian and Sinai plates on the one hand and the Syrian arc on the other. A new tectonic map of the eastern Mediterranean is presented that first of all integrates geophysical satellite-derived gravity and airborne magnetic fields, as well as tectonic-structural, paleogeographical and facial analyses. The results have clear implications for hydrocarbon prospecting in this region.
\end{abstract}

Keywords: Eastern Mediterranean, Isopach Maps, Hydrocarbon Potential, Satellite Gravity, Airborne Magnetics

\section{Introduction}

The eastern Mediterranean is a tectonically complex region evolving in the long term located in the midst of the progressive Afro-Eurasian collision. Its geological-geophysical structure has been studied for years, but is still not completely known. The eastern Mediterranean represents a classic area for the emergence of plate tectonics [2-7]. Recent discoveries of significant hydrocarbon deposits in this region (e.g., [8-10]) have heightened the need for a robust tectonic-structural description to assist in prospecting for hydrocarbon structures. This article reports on a combined geophysical (potential geophysical fields and seismic) and geological (formational, facial, tectonic-structural and paleogeographical) investigation conducted for this purpose.

In the eastern Mediterranean there are three main types of crust: (a) platforms with a Precambrian crust, (b) regions with an oceanic crust, and (c) a folded belt of the transition type with a thinned continental crust [4]. However, the exact boundaries of these zones are not reliably known.

Integrated geophysical data on crust thicknesses [2,4, 11,12] indicate that the folded belt is composed of several terranes (Cyprus, Eratosthenes, the southern part of the Levant Basin (Pleshet), Galilee-Lebanon, Judea- Samaria and Negev) (Figure 1A). Figure 1B shows a velocity-depth distribution of compressional seismic velocities for these terranes (after [4] and [13]). It is obvious that these graphs exhibit different behaviors.

Alongside geophysical investigations, the Mesozoic formations were also mapped. The presence of a large number of deep wells in this region makes it possible to 


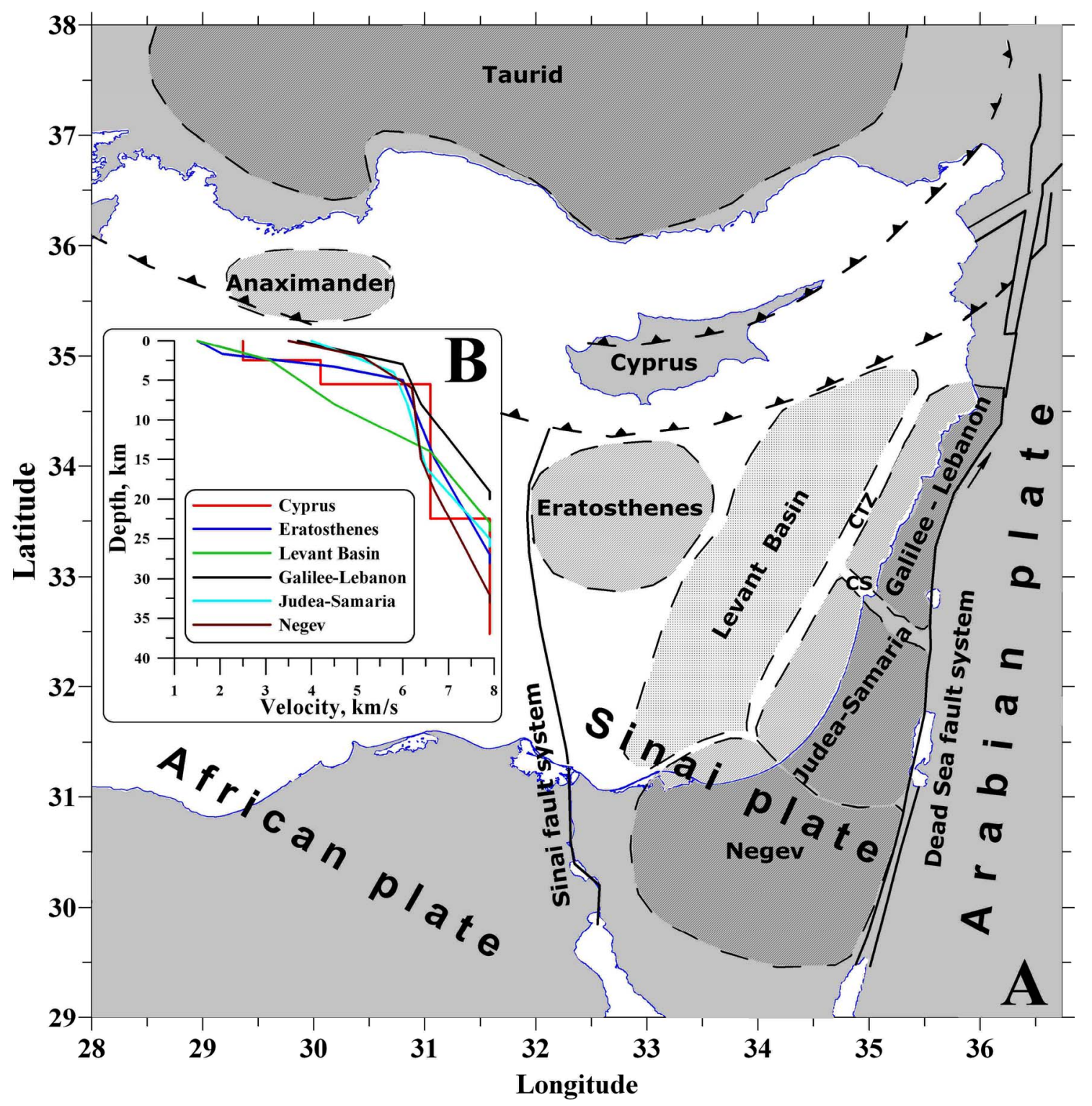

Figure 1. Tectonic scheme of the eastern Mediterranean (A) with generalized seismic sections (B). (A) after [11] and (B) after [4] and [12]. CS, Carmel structure; CTZ, crustal transition zone.

carry out geological mapping of the terranes and their boundaries. For this purpose a series of maps of the Early Mesozoic sedimentary rocks was constructed (here, the two most significant paleogeological maps are presented). These maps confirm an earlier model of continental accretion [2]. They show in particular that abrupt changes in the trend and thickness of the Early Mesozoic formations coincide with the terrane boundaries [14].

In this region numerous seismostratigraphic investigations have been carried out (e.g., [9,10,15-21]). These works have mainly been oriented toward the study of prospective hydrocarbons structures.

\section{A Brief Geological Overview}

According to modern geological-geophysical constructions, the eastern Mediterranean region covers four geotectonic plates: the African, Sinai, Arabian and AegeanAnatolian (Figure 1). The first two plates consist of heterogeneous blocks of continental and oceanic crust and each of these plates is circumscribed by deep faults. According to Robertson et al. [22], the oceanic crust of the eastern Mediterranean is a remnant of the Neotethys. The Sinai plate [22] is bounded from the west and the east by a system of Late Cenozoic deep faults $[3,24]$. The eastern 
part of the eastern Mediterranean is formed by the Dead Sea Fault System (Figure 1) along which about 100 km of left-lateral strike-slip motion has developed [25]. Within this fault system numerous horsts and grabens have emerged. These grabens usually represent pull-apart basins [26] filled by terrigenous evaporite molasses and basic rocks.

Between the oceanic and continental crust is the Syrian fold belt (Syrian arc) (e.g., [5]). This belt is the eastern part of the larger Alpine-Mediterranean fold belt and basin system [6,27]. The structural inhomogeneity of the Syrian arc was revealed by analysis of subsurface Paleogene-Upper Cretaceous sediments [28,29]. However, the tectonic characteristics of the deeper structural stages have been studied to a lesser extent. Geophysically it was shown [2] that a thinned continental crust composes the Syrian arc structure. Tectonically, this belt is made up of a sequence of extensional independent crystal units [11].

Precambrian, Paleozoic, Mesozoic and Cenozoic associations form the geological section of the African and Arabian platforms within the eastern Mediterranean. The Precambrian is known to contain metamorphic and igneous rocks, and in the upper part of Precambrian there is molassa which passes to the Cambrian base. Cambrian rocks are extensive in the Sinai, but are not found in the borehole sections of the Negev desert. In the Negev the Permian deposits overlie the Precambrian arkosic sandstone. In the Heletz block there is no molasses and the Permian deposits are in direct contact with the crystalline schist.

More completely than in the Sinai, Lower Paleozoic sequences are present to the east of the eastern Mediterranean coast in Syria, Jordan and Iran. Analysis of geophysical data testifies to the absence of Lower Paleozoic strata in the Levant Basin and in the Pleshet terrane $[12,17,18]$. Devonian and Carbon deposits have not been detected in the borehole sections of Israel. The Carbon and Permian continental associations were studied in Sinai [30]. Deep boreholes drilled in the Negev, the coastal plain of Israel, the Judean mountains and western Jordan have revealed marine Permian deposits [31,32]. Thus, the Precambrian and Paleozoic associations of the Arabian plate and southern Sinai differ significantly from the folded zone of the Syrian arc.

The Mesozoic and Paleogene associations make up the carbonate platform of the eastern Mediterranean (including reefs and other organogenic constructions). These carbonate associations also include small terrigeneous complexes and traps. The Miocene and Quaternary associations are represented by terregeneous molassa with Early Messinian evaporates, sometimes generating salt domes and diapirs. These associations are developed mainly in the pull-apart basins within the Dead Sea transform zone and Levant Basin [33]. Besides sedimentary deposits, in the eastern Mediterranean there are widely developed Mesozoic and Late Cenozoic magmatic rocks [29,34,35].

\section{Materials and Methods}

The tectonic-geophysical investigation of such a complex region requires careful analysis of numerous materials and data sources such as deep boreholes sections and major outcroppings, geological and geophysical maps, seismic regional constructions and seismostratigraphic examinations, as well as the results from potential geophysical fields.

Here, we utilized and examined more than 200 deep boreholes (isopach constructions were made from more than 120 boreholes) and about 10 of the most significant outcroppings (for instance, such as Jebel Maghara, Makhtesh Ramon and Mt. Hermon) (Figure 2). Data on borehole sections and outcroppings were taken from numerous publications and reports [8,17,19,21,30-32,36-49].

The geological materials included the following data: geological maps of Israel [29], Jordan [50], Egypt [46] and photomaps of Israel and adjacent areas [51]. The following materials on the dating of Mesozoic and Cenozoic magmatic associations were employed: [34,35,47,52,53].

The geophysical data used here encompassed a wide spectrum of geophysical fields. Of primary importance are the geophysical maps that included gravity and magnetic maps of Israel and the Levant [54-56], satellite gravity data [57], a map of the Moho discontinuity for the eastern Mediterranean [58], a map of the Curie discontinuity for Israel [58], the geothermal gradient map of Israel [59] and maps of earthquakes epicenters [60,61]. In addition we drew on the results of regional analyses of seismic, gravity, magnetic and thermal data in this region [2-4,11,13,20,62,63], seismostratigraphic examinations $[10,11,15-21]$, and detailed geophysical-geological studies in separate areas [14,64-74].

For the first time in this region we applied a regional integrated geological-geophysical zonation of deep-seated complexes. A facial-paleogeographical analysis and thickness analysis were conducted mainly for the localization of geological structures of the Early Mesozoic. This analysis was also employed to study both sedimentary and magmatic complexes. Paleobiogeographical examinations were utilized to assess initial positions of the terranes [75]. This integrated methodology was accompanied by a broad examination of previous geological-geophysical research in the region. 
Implications for Hydrocarbon Prospecting

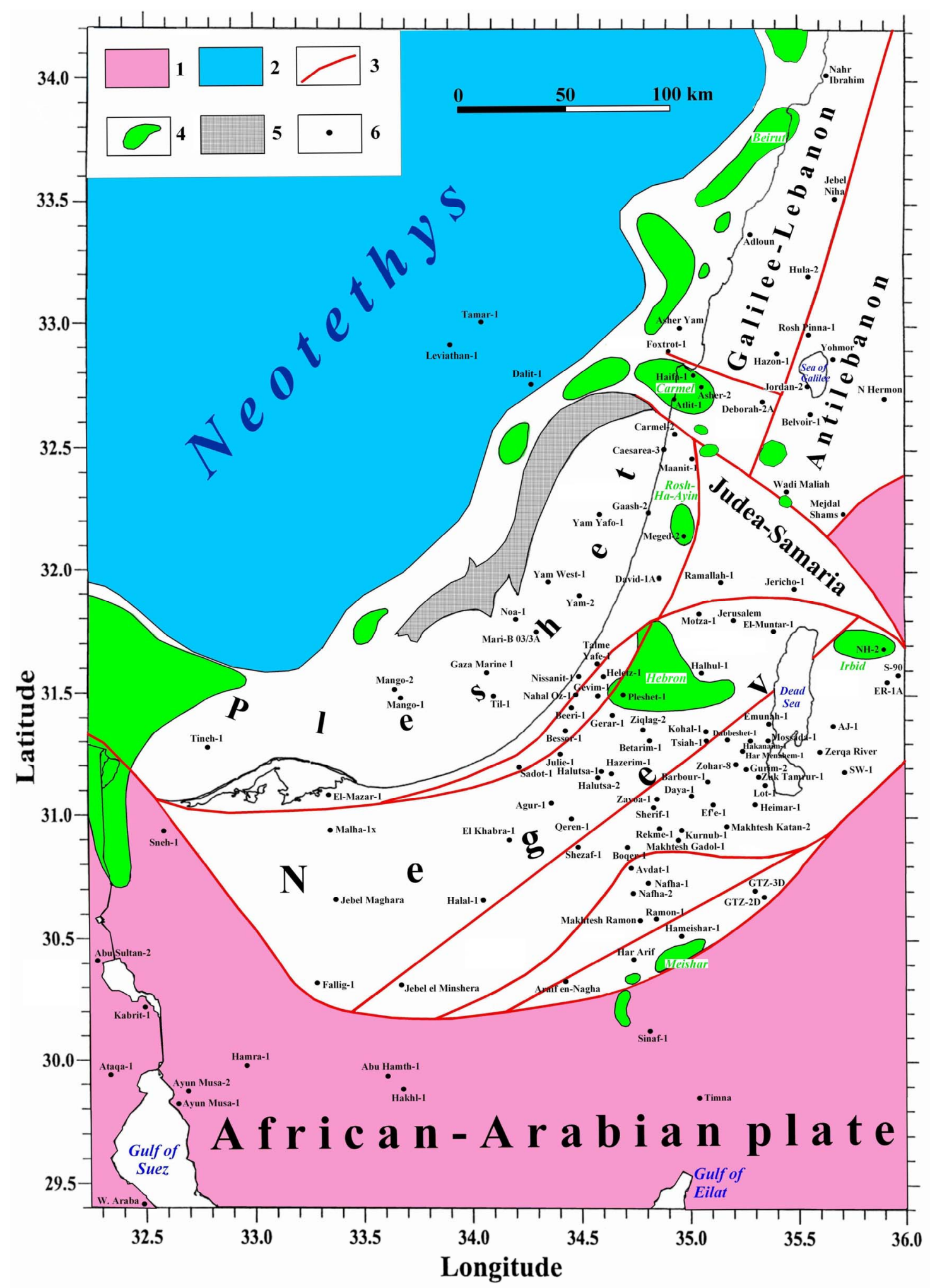

Figure 2. Map of Lower Mesozoic wells and outcrop locations in the eastern Mediterranean with some geological-geophysical zonation. (1) African-Arabian Precambrian plate, (2) Neotethys, (3) main faults, (4) contours of significant magnetic anomalies, (5) marginal erosional zone (Jonah Ridge), (6) deep boreholes and distinctive outcroppings. 


\section{Analysis of Geophysical Fields}

Previous divisions of the area under study for the abovementioned terranes have been made on the basis of comprehensive analyses of seismic, gravity and magnetic data (e.g., [2,4,11,62]). The first Curie map of Israel [58] also correlates with the position of the terranes (e.g., [11]). The sources of the two most significant gravity-magnetic anomalies in Israel - Hebron and Carmel - were classified as phenomena associated with tectonically weakened zones between the terranes $[11,68,69]$.

The satellite gravity data were obtained from the World Gravity DB as retracked from Geosat and ERS-1 altimetry [57]. A highly positive factor is that these observations were made with regular global 1-minute grids [56] and the error of gravity data computation was estimated at 2-3 mGals. The compiled gravity map (Figure 3) shows the intricate gravity pattern of the investigated area (isoline interval is $5 \mathrm{mGal}$; "zero" isoline is dashed and bolded). This figure indisputably proves that in specific cases it is useful to display the gravity field map without any reduction. The selected positive and negative gravity anomalies (Figure 3) clearly reflect the main structural-geotectonical units of the region. The geomorphologic names of the corresponding gravity anomalies were taken from [11,18,32,76,77].

A map of the magnetic field horizontal gradients (Figure 4) was computed (a sliding interval of $2 \times 2 \mathrm{~km}$ was applied) on the basis of an airborne total magnetic field analysis [54]. Some peculiarities of the horizontal magnetic gradient behavior indicate the presence of regional tectonic faults which mark crystal units (terranes and Precambrian platform) in northern Israel. The Cretaceous and Neogene-Quaternary local volcanic eruptions also follow these faults (Figure 4). Magnetoactive rocks producing high gradients generally correspond to surface and subsurface trap complexes, the thicknesses of which depend on the disjunctive tectonics in the region [53,71, 74]. This map indicates that the sharpest gradients (125$750 \mathrm{nT} / \mathrm{km}$ ) correspond to the Precambrian plate. The minimal gradients $(0-12.5 \mathrm{nT} / \mathrm{km})$ correspond to northern part of the Negev, Pleshet, Judea-Samaria and the northern part of the Galilee-Lebanon terranes. The location of the Neogene-Quaternary local volcanic eruptions was used as an additional indicator for the detection of significant faults.

In order to define the position of tectonic boundaries of the main structures in the eastern Mediterranean, an analysis of the regional magnetic anomalies (on the basis of [54] and [56]) was carried out. The main magnetic features it reveals are the high-amplitude anomalies of Hebron [54,68,78], Carmel and Beirut [62], Irbid [78] and Meishar [74] (see Figure 2). Furthermore a lowamplitude anomaly was contoured on this map in RoshHa-Ayin [64] and several unnamed low-amplitude magnetic anomalies associated with the boundaries of terranes. This map shows the positions of the deep boreholes and the most distinctive outcroppings of the Mesozoic sediments utilized for the construction of the series of isopach maps (see below).

\section{Construction of Isopach Maps: Their Relation to Tectonic and Geophysical Patterns}

Isopach maps of the Middle-Upper Jurassic and Lower Cretaceous (Figures 5 \& 6, respectively) were constructed on the basis of a detailed examination of numerous well sections and the most significant outcroppings (a list of references is presented in Materials and Methods). The isopach maps were compiled on classical principles described, for instance, in [79]. A thorough analysis of these maps indicates that practically all the aforementioned terranes (Figure 1) are reflected in the Middle- Upper Jurassic and Lower Cretaceous isopach maps.

The compiled maps also capture significant distinctions between the Arabian and Sinai plates on the one hand and the Syrian arc on the other. Mesozoic associations in the ancient African-Arabian plate are developed to a lesser extent than in the Syrian arc and sometimes are lacking. From a facial point of view $[80,81]$ thin terrigenous marine and continental associations are presented here mainly comparatively. The isopach map of the MiddleUpper Jurassic (Figure 5) indicates that the Cenozoic folded belt of the Syrian arc was formed within the complex system of paleotectonic blocks. These blocks correspond completely to the terranes identified earlier. The isopach map permits, for instance, to define terrane boundaries and to single out some block structures within these terranes. This map indicates that the axes of the terrane and platform paleostructures are located discordantly to each other. The axes of the platform Early Mesozoic eastern Desert [46] and Jebel Druze depression [31] are located at an angle of 90 to the axes of Syrian Arc paleostructures (Figure 5). Analyses of facies and thicknesses of Jurassic deposits show that the Late Cenozoic Dead Sea Transform in the southern part of the region dissects the Anti-Lebanon, Judea-Samaria and Negev terranes and displays their western and eastern blocks for $100 \mathrm{~km}$.

The distribution of the Lower Cretaceous thicknesses (Figure 6) testifies to the lack of influence of the terranes' geotectonic boundaries on sedimentation. Rather, it is caused by the influence of erosion relief forms and denudation processes on the post-accretional sedimenta- 
tion. As can clearly be seen from the map, the relief of the denudation surface is inclined from SE to NW at $1600 \mathrm{~m}$ to the studied region (Figure 6). The depth of erosional cutting reaches $500 \mathrm{~m}$, and in the transition zone of the Tethys Ocean erosional processes have shaped the canyons to a depth exceeding $1000 \mathrm{~m}$. This is an important criterion for regional oil-and-gas prospecting (an example is the Heletz oil deposit - the first oil field discovered in the eastern Mediterranean [82]).

Besides thickness analyses, a facial examination was also carried out. Given the series of bauxite iron-pisolith redbeds of the Jurassic weathering crust, the Negev and Pleshet terranes as well as the northern and southern Palmyride and Heletz blocks are joined to a common tectonic-paleogeographic structure. At the same time the
Galilee-Lebanon terranes and Anti-Lebanon as well as Aleppo belong to another tectonic-paleogeographical zone. The facial analysis highlights that the terranes were isolated structures until the end of Jurassic and the beginning of the Early Cretaceous. Evidently, their movements triggered the formation of dyke complexes with an estimated age of 140 m.y. [47]. The terrane accretion was estimated to be the Lower Cretaceous (Hauterive) [75] after which post-collision traps began to form in this region [74]. Besides these traps, terrigenic and at times carbonate associations were generated.

Thus, the data on the sedimentary thickness distribution provide an unambiguous confirmation of the terrain model of the evolution of the eastern Mediterranean derived from the regional geophysical data analysis [2].

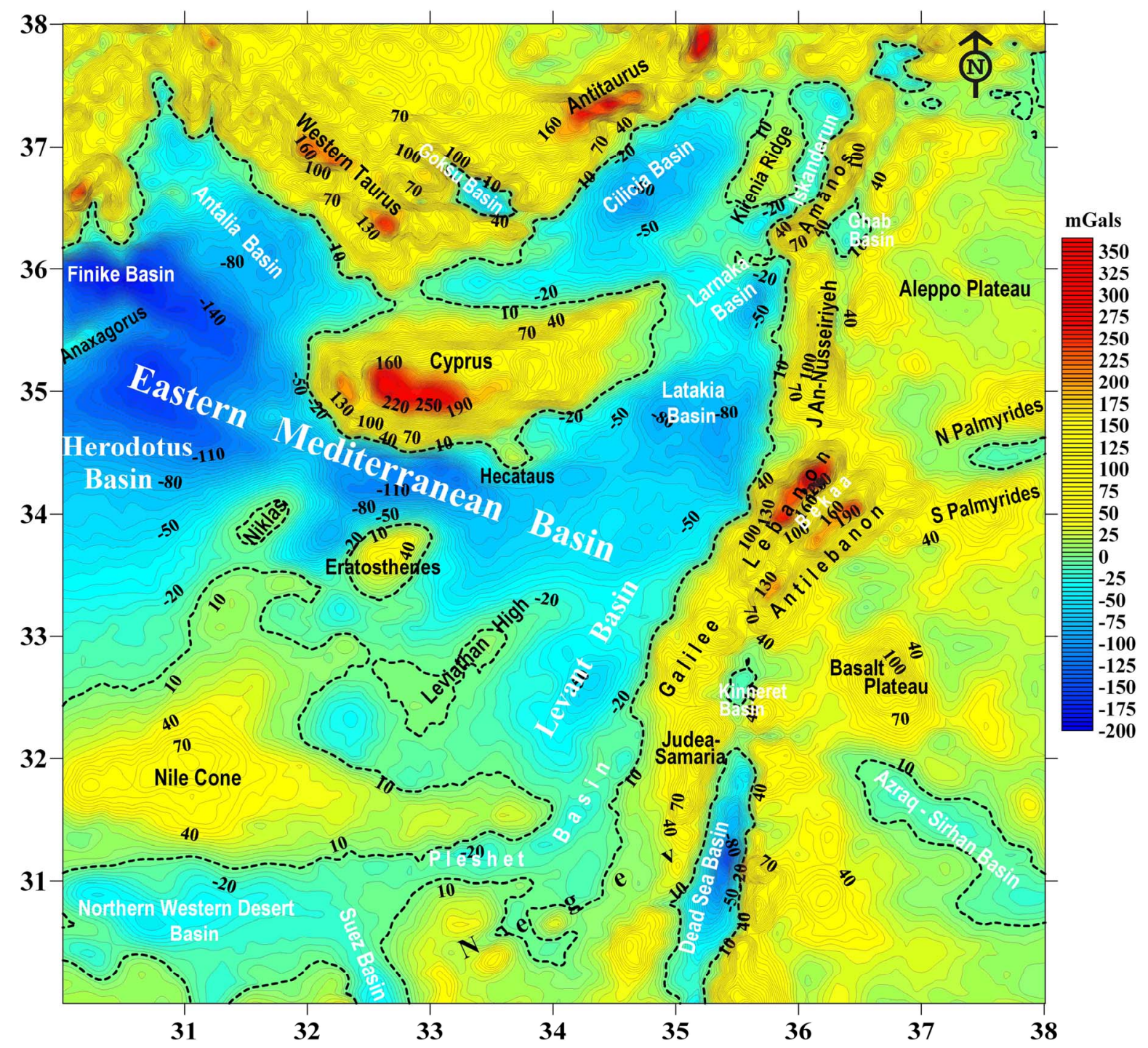

Figure 3. Map of significant gravity anomalies of the eastern Mediterranean and adjacent areas (isolines are given in mGals). 


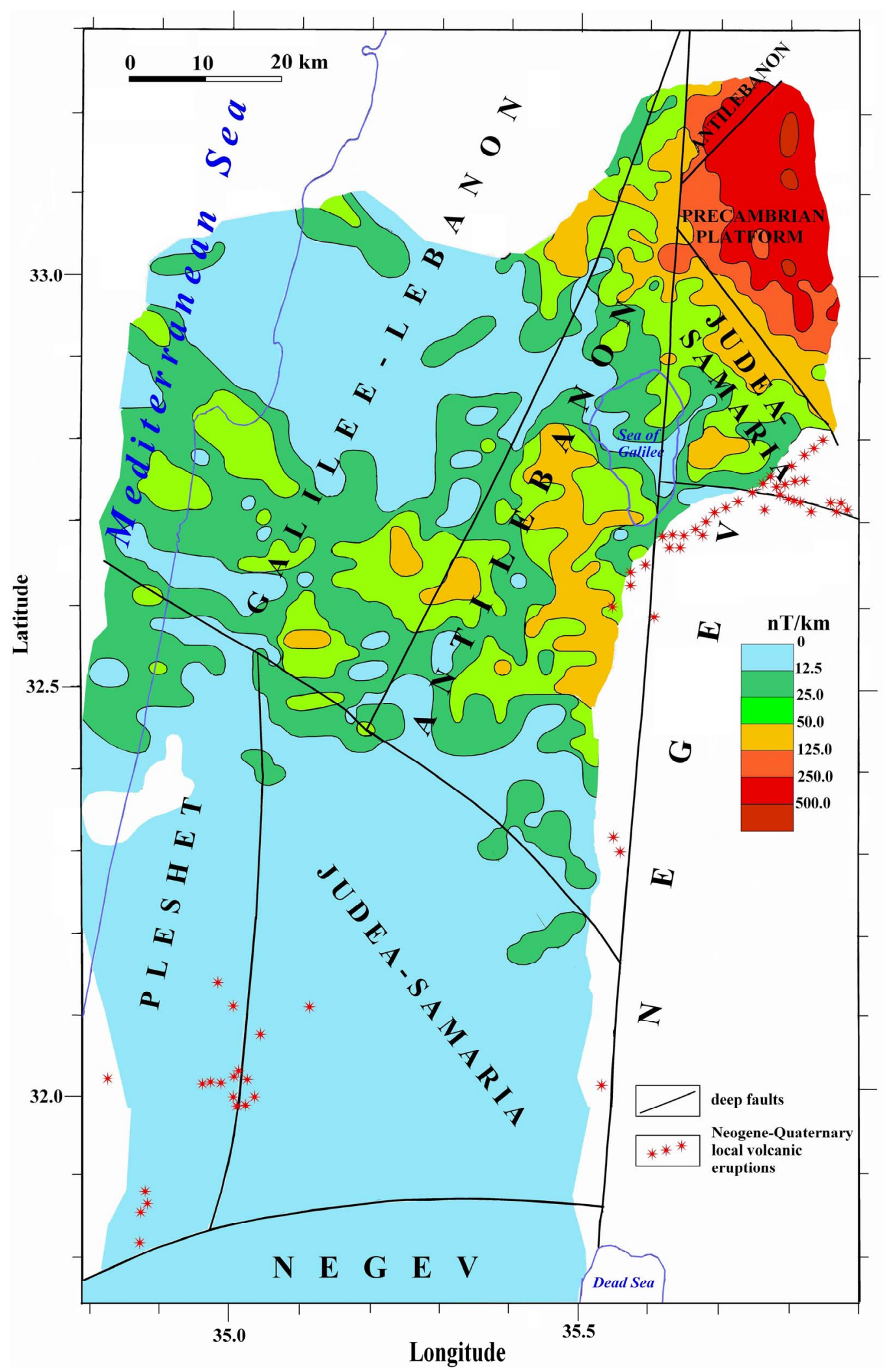

Figure 4. Magnetic gradient map of Israel and some adjacent areas with elements of tectonic analysis. 


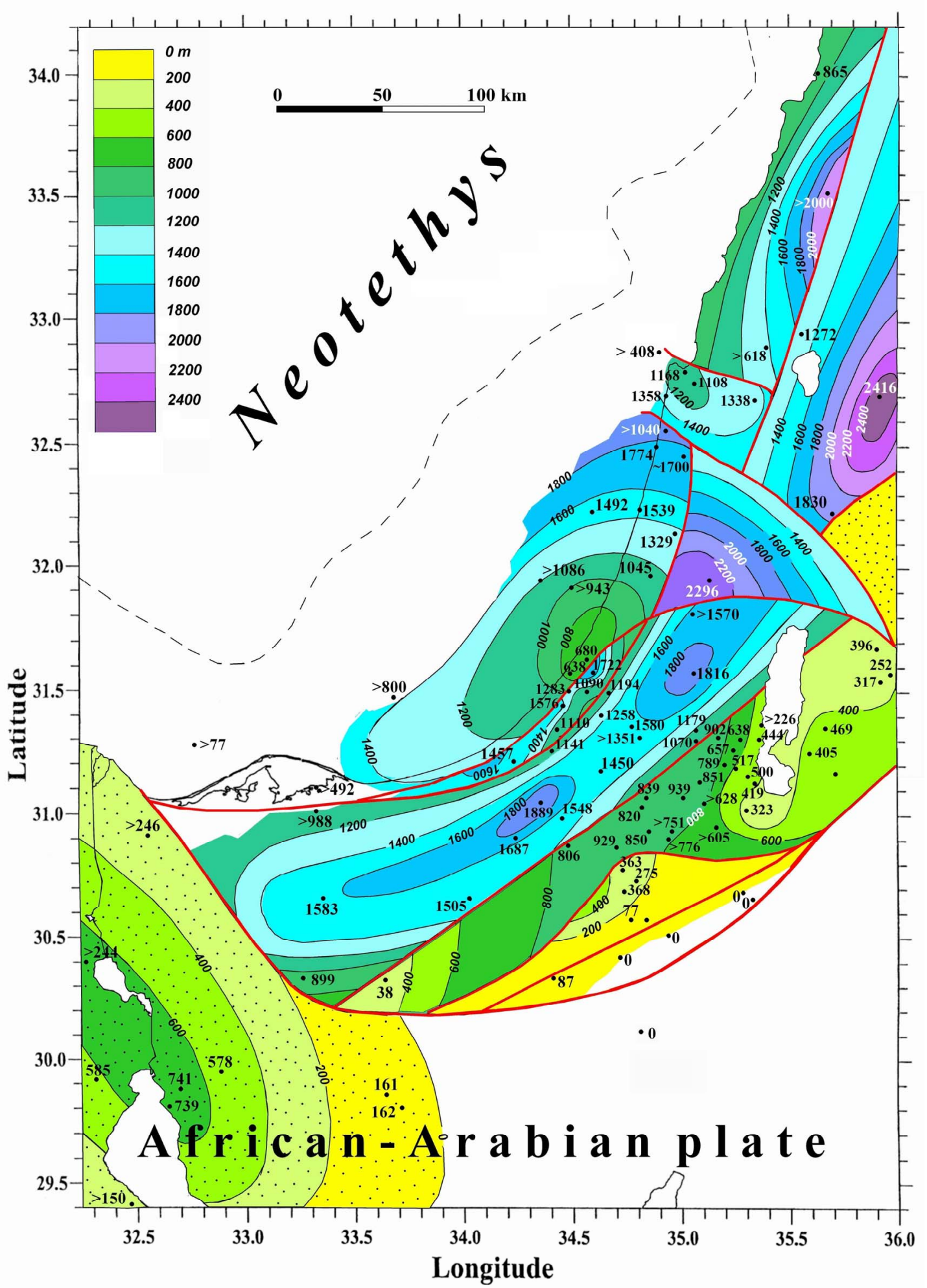

Figure 5. Isopach map of the Middle-Upper Jurassic for the Levant color isopach column is presented in the upper left corner. Black lines with numbers in italics represent isopachs. Numbers next to solid black dots designate determined Bajocian Upper Jurassic thicknesses. Dotted areas show terrigeneous (predominantly continental and shallow marine) deposits (other captions are the same as in Figure 3). 


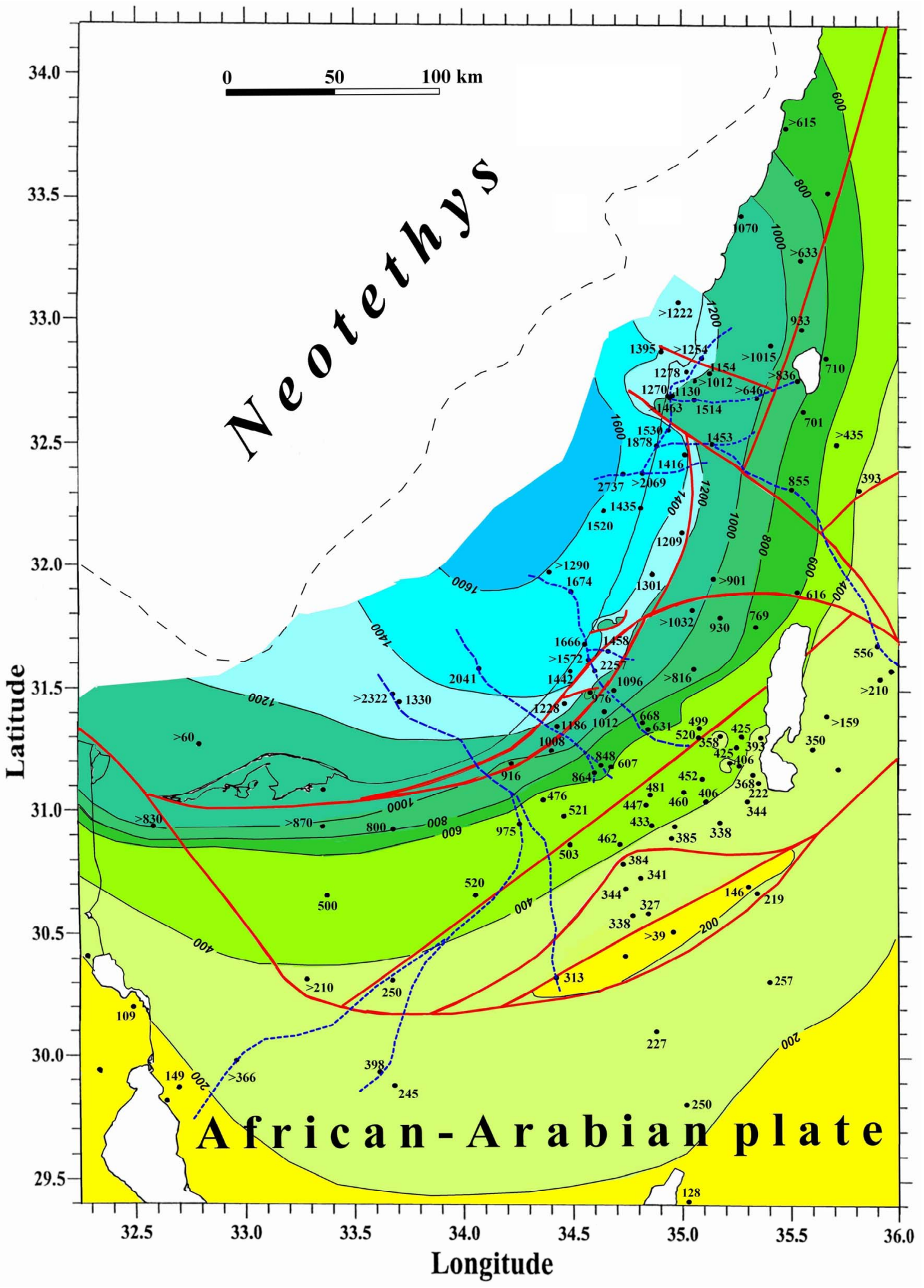

Figure 6. Isopach map of the Lower Cretaceous for the Levant Dashed blue lines designate the position of the ancient erosional system (other captions are the same as in Figures 3 and 4). 


\section{Application of Paleotectonic Zonation in the Heletz-Ashdod Oil Field (Central Israel)}

Deep paleotectonic mapping (zonation) supported by gravity-magnetic examination was used to investigate the hydrocarbon fields of the central plain of Israel (Figures 7-9). In the detail drilled (about 100 boreholes) of the Heletz-Ashdod oil and gas area, paleogeographic and paleotectonic mapping based on the facies analysis was applied and the Jurassic and Cretaceous horizons were studied. Figure 7 shows the Early Cretaceous erosion section at a depth of up to 1000-1300 m, splitting the Jurassic thicknesses down to the Sherif formation of the Late Bajocian. The post-accretional Gevar formation of the Late Hauterivian - Barremian is well known as regards alluvial, deltaic and deep marine channel facies [83].

The structural differentiation of this erosional zone appears both in differences in the integrated thicknesses of Jurassic rocks (Figure 7) and in thicknesses of their separate horizons (Figure 8). The examined geological structures are mainly inherited ones. The Heletz oil field is a triangular depression within which thicknesses of the Upper Jurassic and Lower Cretaceous are sharply increased. The Lower Cretaceous thicknesses in this area offshore Israel reach maximal eastern Mediterranean values in the Heletz-33 (2359 m), Heletz-31 (2257 m) and Heletz-32 (2290 m) boreholes [42]. The Ashdod gas field may be described as an anomalous uplifted zone where thicknesses of the Jurassic and Lower Cretaceous horizons abruptly decrease.

Gravity and magnetic anomalies in the area under study are significantly influenced by some regional anomalies. Therefore, for better visualization, the gravity and magnetic maps are overlaid and also show the geological structural elements (Figure 9). In this integrated map the local structural elements of the oil and gas HeletzAshdod area stand out well. The clearest delineations are the Heletz triangle, Yinnon High, the Beeri depression and Gevim High (Figure 9). Note that the Talme Yafe arch, within which the Ashdod High is located, is characterized by a heterogeneous structure that calls for further detailed geological-geophysical investigation for prospective oil and gas structure detection in this area.

\section{Combined Analysis of Geophysical and Tectonic Indicators as a Basis for Hydrocarbon Prospecting in the Eastern Mediterranean}

The analysis of the regional gravity field (Figure 2) was combined with an integrated examination of the magnetic field [4,84], a thermal field analysis $[4,63,66]$, the Moho discontinuity map of the eastern Mediterranean and the Curie map of Israel [58], maps of earthquake epicenters (e.g., [50,61]), and seismic data analyses (e.g., [4,11]) to construct a modified tectonic map of the Eastern Mediterranean (Figure 10).

The satellite gravity map displays the terranes, the main and intraplate tectonic faults, the African-Arabian Precambrian basement with the continental crust, areas occupied by oceanic crust, Mesozoic terranes and the Alpine tectonic belt (Figure 10). To improve readability, the gravity map was smoothed and the isoline interval was increased to 20 mGals.

This map (Figure 10) was developed on the basis of regional tectonic reconstructions of the eastern Mediterranean [2-4,11-14,22,75,85] and the present investigation. This map depicts the main plate tectonic structures of this region: the African, Arabian, Sinai and Aegean-Anatolian plates. The latter plate is part of the Alpine mobile belt. Associations of the Precambrian continental crust, oceanic crust and Mesozoic accretional complexes compose the African, Arabian and Sinai plates. It should be noted that the earlier (e.g., [86]) Pelusium Line (some 60 $\mathrm{km}$ off the coast of Israel) in the northern part mainly coincides with the boundary between the oceanic crust and the Galilee-Lebanon terrane. Thus, the Pelusium Line cannot be a marker of the northern part of the Sinai plate (Figure 10). At the same time it agrees with the conceptual model proposed by Ben-Avraham [3] where the northern boundary of the Sinai plate collides with the Aegean-Anatolian (Turkish) plate.

In the region under study, several hundred deep boreholes were drilled. Among these roughly 40 known borehole hydrocarbon reserves have been discovered [8, 19,36,40,42,45]. Interestingly, borehole Tamar-1 (where a deposit was discovered with total reserves of more than 200 billion $\mathrm{m}^{3}$ of gas condensate) and the promising prospective borehole Leviathan [9] (the most recent estimates, in January of 2011 report about 450 billion $\mathrm{m}^{3}$ of gas condensate), are located in the vicinity of a positive gravity anomaly (Figure 10). The last U. S. Geological Survey estimate indicates the presence of 1.7 billion barrels of recoverable oil and more than 4 trillion $\mathrm{m}^{3}$ of recoverable gas in the Levant Basin Province [1].

Integrated methodology of the regional-structural, facial and paleo-geodynamical analysis can serve to estimate the overall hydrocarbon potential in the eastern Mediterranean. For the first time three structural-prognosis geotectonic zones for hydrocarbon prospection were revealed: 1 ) a province located on the ancient $\mathrm{Nu}-$ bian-Arabian Precambrian platform, 2) a province of a terrane belt with thinned Precambrian crust, and 3) a province of basins with oceanic crust. 


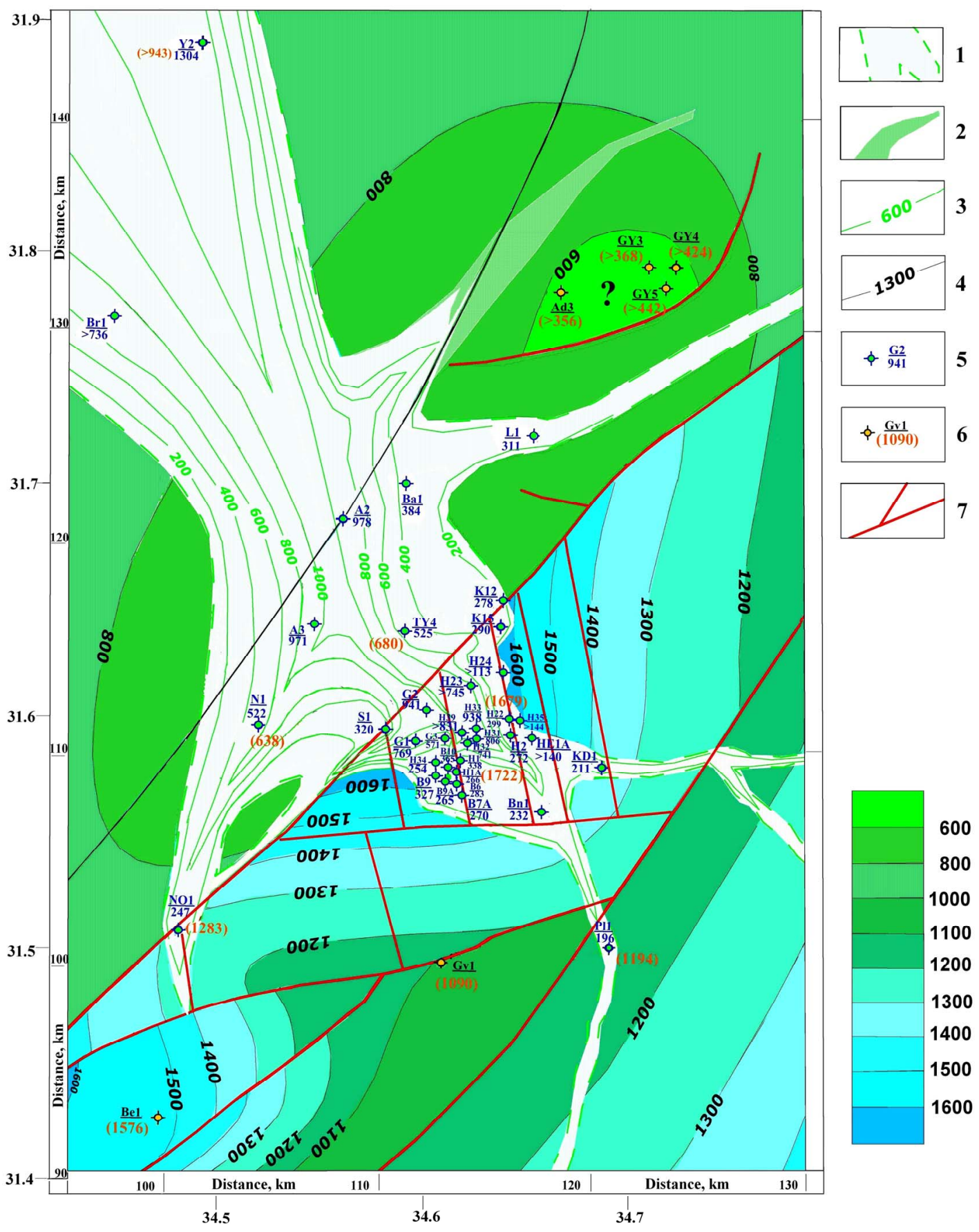

Figure 7. Paleogeomorphological map of GevarAm erosional stage (Hauterivian - Barremian) of the Heletz-Ashdod oil and gas field and adjacent areas. (1) Gevar Am deltaic, alluvial and marine canyon zone, (2) zone of posterior Gevar Am denudation, (3) isopachs of the Gevar Am formation (in m), (4) isopachs of the Upper - Middle Jurassic (Halutza - Upper Inmar formations) (in m), (5) boreholes penetrating Gevar Am formation (numerator - borehole name and number, denominator thickness in $\mathrm{m}$, (6) boreholes penetrating Jurassic rocks (numerator - borehole name and number, denominator - thickness in m), (7) faults. Borehole abbreviations: A - Ashkelon, Ad - Ashdod, B - Brur, Ba - Barnea, Be - Beeri, Bn - Binyamin, Br Bravo, BW - Beeri West, G - Gevar Am, Gi - Givati, Gv - Gevim, GY - Gan Yavne, H - Heletz, Hd - Hodiya, Ho - Hoga, HE - Heletz East, K - Kokhav, Kr - Karmon, KD - King David, L - lior, MY - Massuot Yizhak, N - Nissanit, Ng - Negba, NA - Nir Am, NO - Nahal Oz, PI - Pleshet, Rv - Revaha, S - Shimon, Sa - Saad, Sh - Shuva, SA - Sedot Akiva, TY - Talme Yafo, Y - Yam, Ya - Yakhini, Yi - Yinnon Color columns show the Middle - Upper Jurassic isopach intervals (in $\mathrm{m}$ ). 


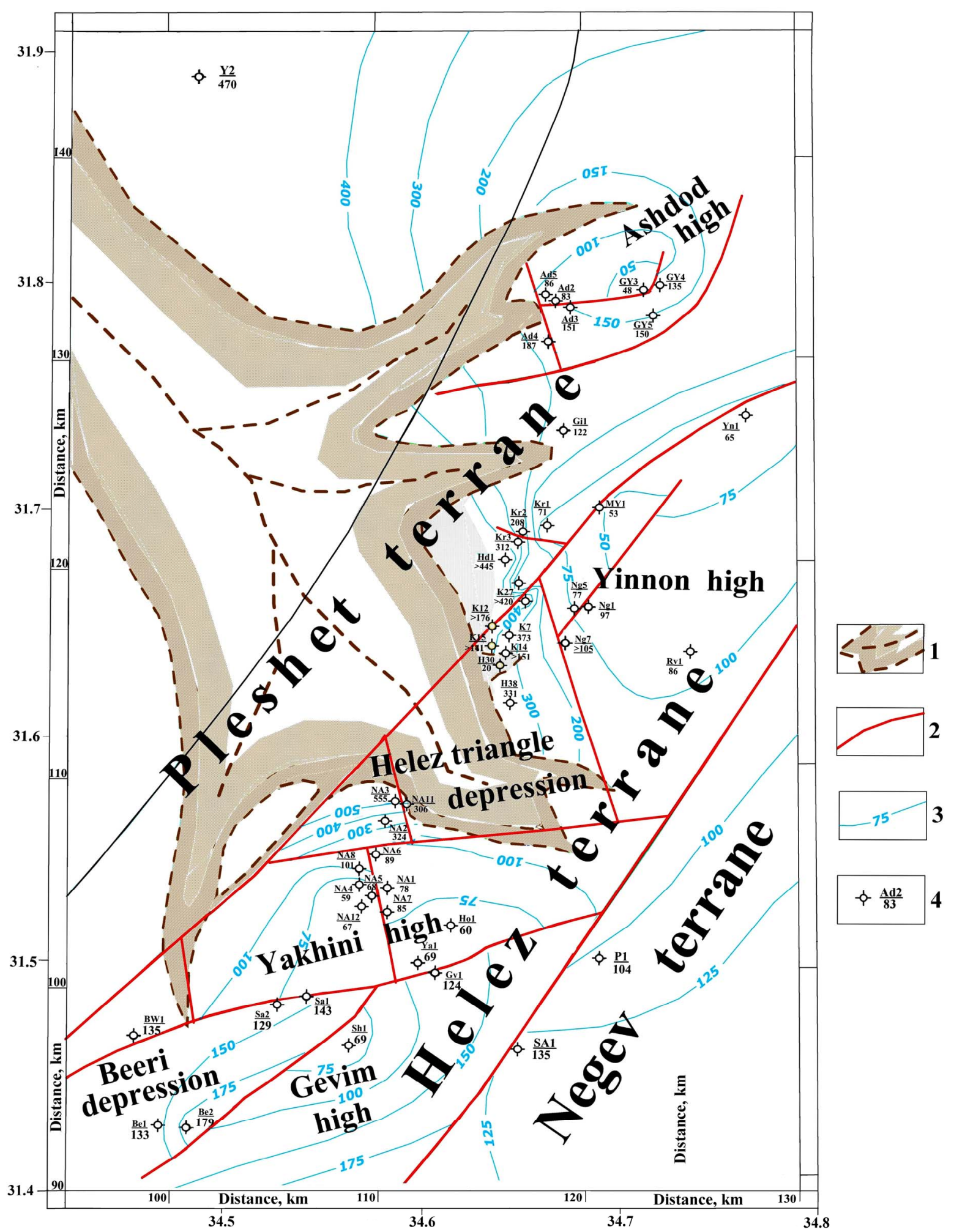

Figure 8. Late Hauterivian - Barremian structural-paleogeographic map of the Heletz-Ashdod oil-gas field and adjacent areas. (1) The Early Cretaceous Gevar Am) erosoinal zone, (2) isopachs of the Middle Oxfordian (Beer Sheva formation) (in m), (3) boreholes penetrating the Beer Sheva formation (numerator - borehole name and number (see caption to Figure 7), denominator - thickness in $\mathrm{m}$ ), (4) faults. 


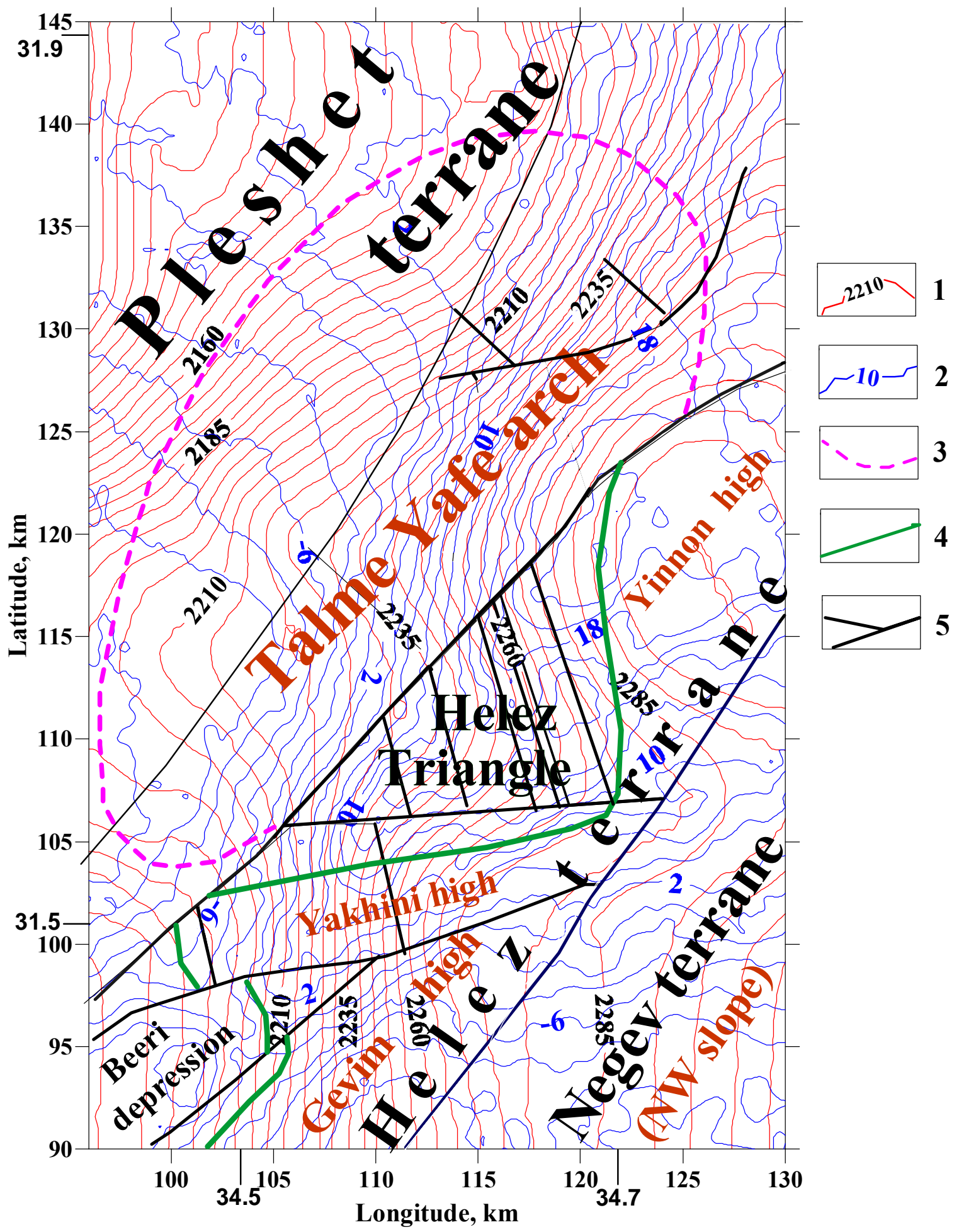

Figure 9. Combined gravity-magnetic map overlaid on the Late Jurassic-Early Cretaceous paleotectonic structure of the Heletz-Ashdod oil and gas field and adjacent areas. (1) isolines of Bouguer anomalies (in mGal), (2) isolines of magnetic anomalies (in $\mathrm{nT}$ ), (3) isopach $800 \mathrm{~m}$ of the Middle - Upper Jurassic rocks in the Pleshet terrane, (4) isopach $1300 \mathrm{~m}$ of the Middle Upper Jurassic rocks in the Heletz terrane, (5) faults. The gravity and magnetic maps were constructed using the Gravity-Magnetic Database compiled by the Geophysical Institute of Israel. 


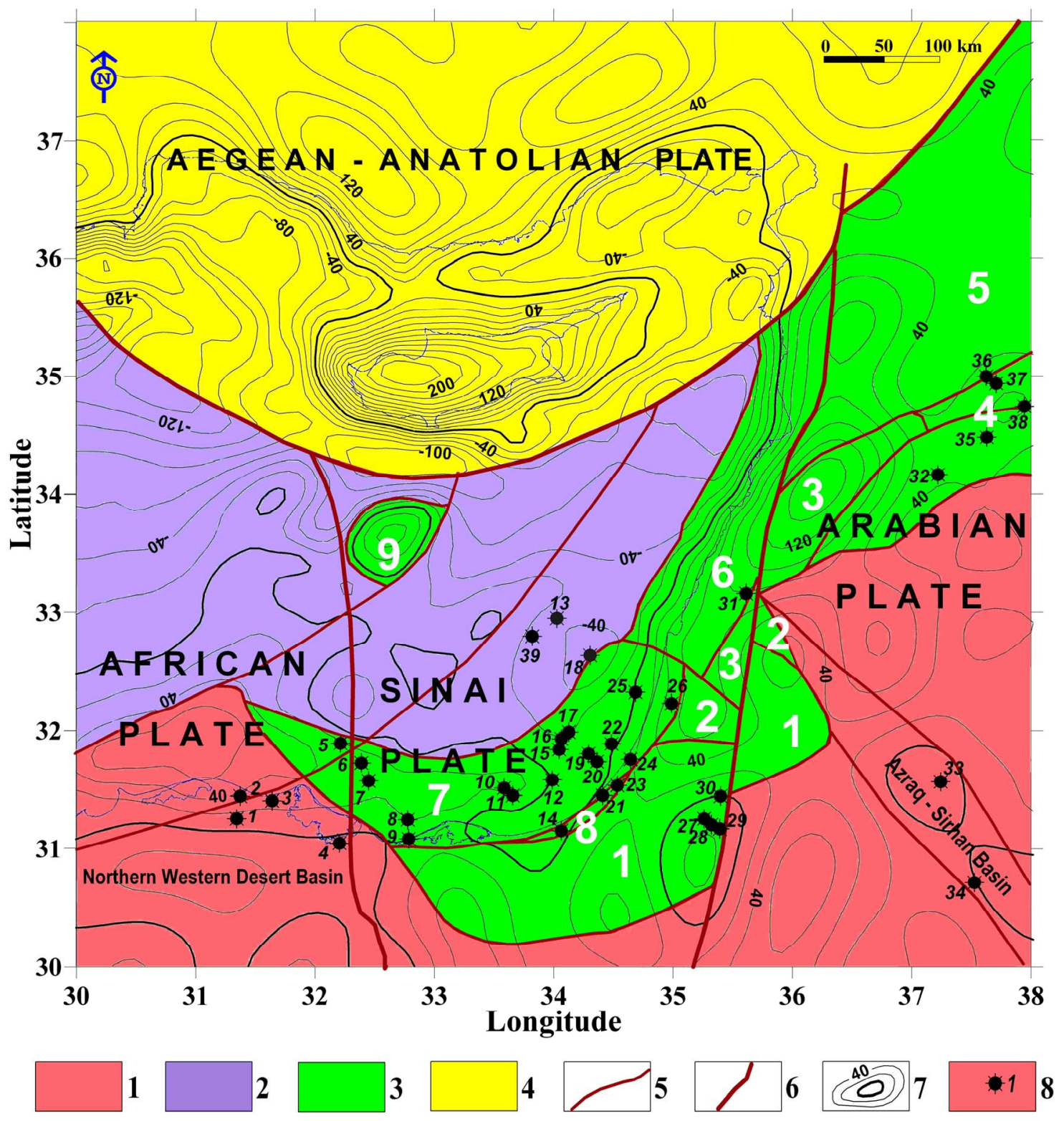

Figure 10. Tectonic map of the eastern Mediterranean overlaid on the smoothed gravity map. Terranes position (white numbers): 1 - Negev, 2 - Judea-Samaria, 3 - Antilebanon, 4 - Palmyride, 5 - Aleppo, 6 - Galilee-Lebanon, 7 - Pleshet, 8 - Heletz, and 9 - Eratosthenes. (1) Precambrian plates with continental crust, (2) oceanic crust, (3) Mesozoic terranes, (4) Alpine tectonic belt, (5) main tectonic faults, (6) intraplate tectonic faults, (7) gravity isolines, mGal, (8) boreholes with discovered hydrocarbon reserves (black numbers): 1 - Khelala-1, 2 - El-Qara-1, 3 - Wastani-1, 4 - Qnantara-1, 5 - Temsah-1, 6 - Kersh-1, 7 - Port Fouad-1, 8 - Tineh-1, 9 - Bougaz-1, 10 - Mango-1, 11 - Mango-2, 12 - Gaza Marine, 13 - Tamar-1, 14 - Sadot-1, 15 - Noa South-1, 16 - Noa-1, 17 - Or-1, 18 - Dalit-1, 19 - Mari-1,2, 20 - Nir-1,2, 21 - Shiqma-1, 22 - Yam-2, 23 - Heletz, 24 Ashdod, 25 - Yam-Yafo-1, 26 - Meged-2, 27 - Zahar-8, 28 - Gurim-1, 29 - Zuk-Tamrur-4, 30 - Emunah-1, 31 - Hula, 32 Qaruateine-1, 33 - Hamza, 34 - Wadi Sirhan-4, 35 - Cheriffe-1, 36 \& 37 - boreholes with unknown names, 38 - Al Shaier-1, 39 - Leviathan-1.

The hydrocarbon basins of the first province are narrow, intraplate marginal graben-like troughs. Their formation was initiated in the Late Cretaceous era. However, the main stage of their development and hydrocarbon migration are associated with new Neotectonics epochs
(30 m.y.a. - to present) and are connected to the Red Sea system riftogenesis. There are known oil deposits (October and other oil fields in the Suez Basin) [87], ozocerites (Dead Sea Basin) [88] and small gas deposits (Hula Basin) [89]. The prospects for oil and gas discov- 
ery are associated with the presence of a thick series of the Early Messinian salt.

In the second province, three structural floors have developed in a sedimentary cover: (a) Late Precambrian molasses, (b) the Pre-accretional carbonate platform of the Late Permian - Early Mesozoic, and (c) the Postaccretional Late Mesozoic-Cenozoic predominantly terrigenic complex. Oil and gas deposits were found in floors (b) and (c). The carbonate platform (b) has thickness up to 5-6 $\mathrm{km}$ and hydrocarbon searching is oriented here to discovering reef traps. The present investigation helps define a search strategy for these objects based on a combined historical-geodynamical and paleogeographical examination. Taking into account that the thick Mesozoic carbonate series were formed in terranes of the peripheral zones of the Tethys Ocean, the presence of reef complexes and the backreef sediments in this region is obvious. A predominantly terrigenic complex (c) mostly developed in the coastal plain of the eastern Mediterranean and directly in the shelf zone (its thickness reaches 5-6 km). Hydrocarbon collectors in this area are the Late Cenozoic terrigeneous rocks associated with Late Messinian salt. The Early Cretaceous erosional channel complexes are of special interest. The long-term Heletz oil deposit (central Israel) (see Section 6 and Figures 7-9) belongs to just this type. In the Early Cretaceous paleogeographical map (Figure 6) for the first time a complex system of ancient erosional channels is shown. Therefore, this map could be used for hydrocarbon investigation in this region. The presence of a majority of hydrocarbon deposits and a geotectonic basis in the Pleshet terrane (Figure 10) is confirmed by the present work. In this terrane terrigene-carbonaceous rocks and salt predominantly occur. Such a facial type is known in many oil and gas provinces worldwide.

The third province consists of many basins, but our analysis focuses solely on the largest Levant basin (Figures 1,2,10). The tectonic-geophysical analysis was used to designate these basin boundaries with respect to the zone of terrane belt and other eastern Mediterranean basins of this province. The western part of this basin is bounded by the Leviathan high and eastern part - by the continental-ocean transition zone (Figure 10). Note that in the central part of the Levant basin a Moho discontinuity lowering-in was detected previously (see Figure 3 in [58]). The Early Mesozoic-Cenozoic facial characteristics of the sedimentary cover are similar to the corresponding cover of the Pleshet terrane. The available data indicate that structural zones have developed here of the oceanic type as found in the Gulf of Mexico, the Pricaspian basin and the southern Caspian basin. Ben-Avraham [3] claims that there are intensive geodynamic movements at the boundary of the Sinai and Aegean-Anatolian plates allow us to suggest that in the Levant basin numerous prospective local structures and swells may occur. Hence, it is likely that the high-potential hydrocarbon deposits in Tamar-1 and Leviathan (Figure 10) discovered recently in this region are not isolated features.

\section{Conclusions}

This article presented the results of combined structural isopach map compilations and geophysical field analyses of the deep floors of the eastern Mediterranean region, thus constituting the first deep geological-geophysical mapping ever produced. For the construction of the isopach maps of the Middle-Upper Jurassic and Lower Cretaceous a regional structural analysis method was applied (previously employed mainly for mapping subsurface structures in this region). The same analysis for zoning the Heletz-Ashdod oil field was successfully applied. It revealed that the Syrian arc is an accretional belt of the Mesozoic terranes, which was formed in the Early Cretaceous. It was shown that in the Early Cretaceous post-accretional stage numerous erosional channels, which may be used for searching for hydrocarbon col- lectors, were formed. An integrated methodology of regional-structural, paleogeographical and paleogeodynamical analysis was used to estimate the overall hydrocarbon potential of the eastern Mediterranean. Three structural-prognosis geotectonic zones for hydrocarbon prospecting were delineated: 1 ) a province located on the ancient Nubian-Arabian Precambrian platform, 2) a province of a terrane belt with a thinned Precambrian crust, and 3) a province of basins with oceanic crust.

\section{Acknowledgements}

The authors would like to thank Prof. Zvi Ben-Avraham (Tel Aviv University) for useful discussions and comments that were very helpful in preparing the manuscript. Comments of Dr. A. Pilchin (Canada) and two anonymous reviewers were essentially practical ones. The authors also thank the Geophysical Institute of Israel for the permission to use the Gravity-Magnetic Database of Israel and the eastern Mediterranean.

\section{REFERENCES}

[1] C. J. Schenk, M. A. Kirschbaum, R. R. Charpentier, T. R. Klett, M. E. Brownfield, J. K. Pitman, T. A. Cook and M. E. Tennyson, "Assessment of Undiscovered Oil and Gas Resources of the Levant Basin Province, Eastern Mediterranean,” U. S. Geological Survey Fact Sheet, 20103014, 2010.

[2] Z. Ben-Avraham and A. Ginzburg, "Displaced Terranes and Crustal Evolution of the Levant and the Eastern Me- 
diterranean,” Tectonics, Vol. 9, No. 4, 1990, pp. 613- 622. doi:10.1029/TC009i004p00613

[3] Z. Ben-Avraham, "The Structure and Tectonic Setting of the Levant Continental Margin, Eastern Mediterranean,” Tectonophysics, Vol. 46, No. 3-4, 1978, pp. 313-331. doi:10.1016/0040-1951(78)90210-X

[4] Z. Ben-Avraham, A. Ginzburg, J. Makris and L. Eppelbaum, "Crustal Structure of the Levant Basin, Eastern Mediterranean,” Tectonophysics, Vol. 346, No. 1-2, 2002, pp. 23-43. doi:10.1016/S0040-1951(01)00226-8

[5] Z. Garfunkel, "Constrains on the Origin and History of the Eastern Mediterranean Basin,” Tectonophysics, Vol. 298, No. 1-3, 1998, pp. 5-35. doi:10.1016/S0040-1951(98)00176-0

[6] V. E. Khain, "Regional Geodynamics. Alpine Mediterranean Belt,” Nedra Publishing, Moscow, 1984.

[7] A. H. F. Robertson and J. E. Dixon, "Introduction: Aspects of the Geological Evolution of the Eastern Mediterranean,” In: J. E. Dixon and A. H. F. Robertson, Eds., The Geological Evolution of the Eastern Mediterranean, Geological Society Special Publishing Vol. 17, 1984, pp. 1-74.

[8] “Tamar Oil Find Fires Interest in East Mediterranean Data," First Break, Vol. 27, No. 6, 2009, p. 47.

[9] “Noble Identifies Giant Prospect Offshore Israel," Offshore, Vol. 70, No. 5, June 2010. http://www.offshoremag.com/index/article-display/6855731723/articles/off-s hore/field-development/middleeast/2010/06/noble-identif ies_giant.html

[10] "Eastern Mediterranean Prospects Buoyed by USGS Assessment," First Break, Vol. 28, No. 6, 2010, p. 23.

[11] Z. Ben-Avraham, U. Schattner, M. Lazar, J. K. Hall, Y. Ben-Gai, D. Neev and M. Reshef, "Segmentation of the Levant Continental Margin, Eastern Mediterranean,” Tectonics, Vol. 25, No. TC5002, 2006, p. 17.

[12] Z. Cohen, V. Kaptsan and A. Flexer, "The Tectonic Mosaic of the Southern Levant: Implications for Hydrocarbon Prospects,” Journal of Petroleum Geology, Vol. 13, No. 4, 1990, pp. 437-462. doi:10.1111/j.1747-5457.1990.tb00858.x

[13] J. Mechie, K. Abu-Ayyash, Z. Ben-Avraham, R. El-Kelani, I. Qabbani and M. Weber, "Crustal Structure of the Southern Dead Sea Basin Derived from Project DESIRE Wide-Angle Seismic Data,” Geophysical Journal International, Vol. 178, No. 1, 2009, pp. 457-478. doi:10.1111/j.1365-246X.2009.04161.X

[14] Y. Katz, Z. Ben-Avraham and L. Eppelbaum, "Early Mesozoic Facial Distribution and Tectonic-Geophysical Setting in Israel," Transactions of the Conference of the Israel Geology Social Annual Meeting, Neve Zohar, Dead Sea, 2007, p. 59.

[15] A. A. Aal, A. El Barkooky, M. Gerrits, H. Meyer, M. Schwander and H. Zaki, "Tectonic Evolution of the Eastern Mediterranean Basin and Its Significance for Hydrocarbon Prospectivity in the Ultra-Deep Water of the Nile Delta,” The Leading Edge, Vol. 19, 2000, pp. 1086-1102. $\underline{\text { doi: } 10.1190 / 1.1438485}$
[16] Y. Druckman, D. Gill, L. Fleischer, E. Gelbermann and O. Wolff, "Subsurface Geology and Structural Evolution of the Northwestern Negev, Southern Israel,” Israel Journal of Earth Science, Vol. 44, 1995, pp. 115-135.

[17] M. A. Gardosh, Z. Garfunkel, Y. Druckman and B. Buchbinder, "Tethyan Rifting in the Levant Region and Its Role in Early Mesozoic Crustal Evolution," Geological Society of London, Vol. 341, 2010, pp. 9-36. doi:10.1144/SP341.2

[18] M. A. Gardosh, Y. Druckman, B. Buchbinder and M. Rybakov, "The Levant Basin Offshore Israel: Stratigraphy, Structure, Tectonic Evolution and Implications for Hydrocarbon Exploration,” GII 429/328/08, Geological Institute of Israel, 2008, pp. 1-118.

[19] G. Roberts and D. Peace, "Hydrocarbon Plays and Prospectivity of the Levantine Basin, offshore Lebanon and Syria from Modern Seismic Data," GeoArabia, Vol. 12, No. 3, 2007, pp. 99-124.

[20] H. Shulman, M. Reshef and Z. Ben-Avraham, "The Structure of the Golan Heights and Its Tectonic Linkage to the Dead Sea Transform and the Palmyrides Folding,' Israel Jour. of Earth Science, Vol. 53, No. 3, 2004, pp. 225-237. doi:10.1560/MWVC-CGPU-65KU-FFPY

[21] J. Steinberg, Z. Gvirtzman, H. Gvirtzman and Y. Ben-Gai, "Late Tertiary Faulting along the Coastal Plain of Israel," Tectonics, Vol. 27, No. TC4014, 2008.

[22] A. H. F. Robertson, P. D. Clift, P. J. Degnan and G. Jones, "Palaeogeographic and Palaeotectonic Evolution of the Eastern Mediterranean Neotethys," Palaeogeography, $\mathrm{Pa}$ laeoclimatology, Palaeoecology, Vol. 87, 1991, pp. 289343. doi:10.1016/0031-0182(91)90140-M

[23] D. P. Mckenzie, D. Davies and P. Molnar, "Plate Tectonics of the Red Sea and East Africa,” Nature, Vol. 226, No. 5242, 1970, pp. 243-248. doi:10.1038/226243a0

[24] Y. P. Malovitskiy, E. M. Emelyanov, O. V. Kazakov, V. N. Moskalenko, G. V. Osipov, K. M. Shimkus and I. S. Chumakov, "Geological Structure of the Mediterranean Sea Floor (Based on Geological-Geophysical Data)," Marine Geology, Vol. 18, 1975, pp. 231-261. doi:10.1016/0025-3227(75)90015-8

[25] L. Dubertret, "Les Formes Structurales de la Syrie et de la Palestine,” Comptes rendus de l'Académie des Sciences, Paris, Vol. 195, 1932, pp. 66-68.

[26] S. Cloetingh, Z. Ben-Avraham, W. Sassi and F. Horvath, "Dynamics of Basin Formation and Strike-Slip Tectonics,” Tectonophysics, Vol. 449, No. 1-4, 1996, pp. 1-10. doi:10.1016/S0040-1951(96)00179-5

[27] W. Bosworth, A. S. El-Hawat, D. E. Helgelson and K. Burke, "Cyrenacian 'Shock Absorber' and Associated Inversion Strain Shadow in the Collision Zone of Northeast Africa,” Geology, Vol. 36, No. 9, 2008, pp. 695-698. doi:10.1130/G24909A.1

[28] A. Flexer, "Late Cretaceous Palaeogeography of Northern Israel and Its Significance for the Levant Geology," $\mathrm{Pa}$ laeogeography, Palaeoclimatology, Palaeoecology, Vol. 
10, 1971, pp. 293-316.

doi:10.1016/0031-0182(71)90053-8

[29] A. Sneh, Y. Bartov and M. Rozensaft, "Geological Map of Israel, Scale 1:200,000,” Geological Survey of Israel, Ministry of National Infrastructure, Jerusalem.

[30] Y. Druckman, T. Weissbrod, M. Goldberg and S. Boehm, "Lithological and Stratigraphic Data on the Precambrian, Paleozoic, Triassic and Jurassic Subsurface Sequences Penetrated in the Negev and Northern Sinai,” Geological Survey of Israel, Mapping, Stratigraphy and Oil Division, 1983.

[31] I. J. Andrews, "Permian, Triassic and Jurassic Lithostratigraphy of the Subsurface of Jordan," Subsurface Geology Bulletin, Vol. 4, 1992, pp. 1-60.

[32] J. K. Hall, V. A. Krasheninnikov, F. Hirsch, C. Benjamini and A. Flexer, Eds., "Geological Framework of the Levant," Volume II: The Levantine Basin and Israel, Jerusalem, 2005.

[33] Z. Ben-Avraham, "Development of Asymmetric Basins along Continental Transform Faults," Tectonophysics, Vol. 215, 1992, pp. 209-220. doi:10.1016/0040-1951(92)90082-H

[34] Z. Garfunkel, "Tectonic Setting of Phanerozoic Magmatism in Israel,” Israel Journal of Earth Science, Vol. 38, No. 2-4, 1989, pp. 51-74.

[35] A. Segev, "Synchronous Magmatic Cycles during the Fragmentation of Gondwana: Radiometric Ages from the Levant and Other Provinces,” Tectonophysics, Vol. 325, No. 3-4, 2000, pp. 257-277. doi:10.1016/S0040-1951(00)00122-0

[36] A. S. Alsharhan and M. G. Salah, "Geologic Setting and Hydrocarbon Potential of North Sinai, Egypt,” Bulletin of Canadian Petroleum and Geology, Vol. 44, No. 4, 1996, pp. 615-631.

[37] I. J. Andrews, "Cretaceous and Paleogene Lithostratigraphy of the Subsurface of Jordan," Subsurface Geology Bulletin, No. 5, 1992, pp. 1-60.

[38] Y. Bartov, Z. Lewy, G. Steinitz and I. Zak, "Mesozoic and Tertiary Stratigraphy, Paleogeography and Structural History of the Gebel Areif en Naqa Area, Eastern Sinai," Israel Journal of Earth Science, Vol. 29, 1980, pp. 114139.

[39] Z. R. Beydoun, "Some Open Questions Relating to the Petroleum Prospects of Lebanon,” Journal of Petroleum Geology, Vol. 3, No. 3, 1981, pp. 303-314. doi:10.1111/j.1747-5457.1981.tb00932.x

[40] Z. R. Beydoun, A. R. Futyan and A. H. Jawzi, "Jordan Revisited: Hydrocarbons Habitat and Potential,” Journal of Petroleum Geology, Vol. 17, No. 2, 1994, pp. 177-194. doi:10.1111/j.1747-5457.1994.tb00125.x

[41] Y. Druckman, "The Triassic in Southern Israel and Sinai. A Sedimentological Model of Marginal Epicontinental Marine Environments,” Ph.D. Thesis, Hebrew University, Jerusalem, 1976, p. 188.

[42] L. Fleischer and A. Varshavsky, “A Lithostratigraphic
Data Base of Oil and Gas Wells Drilled in Israel," Ministry of National Infrastructures of Israel, 2002-2010.

[43] V. A. Krasheninnikov, J. K. Hall, F. Hirsch, H. Benjamini and A. Flexer, "Geological Framework of the Levant,” Volume 1: Cyprus and Syria, Jerusalem, 2005.

[44] Z. Lewy and M. Raab, "Mid-Cretaceous Stratigraphy of the Middle East," Annales de Museum d'Histoire National de Nice, Vol. 4, No. 32, 1976, pp. 1-19.

[45] F. H. Nader and R. Swennen, "Petroleum Prospects of Lebanon: Some Remarks from Sedimentological and Diagenetic Studies of Jurassic Carbonates," Marine and Petroleum and Geology, Vol. 21, No. 4, 2004, pp. 427- 441. doi:10.1016/S0264-8172(03)00095-3

[46] R. Said, Ed., “The Geology of Egypt,” A. A. Balkema/ Rotterdam/Brookfield, 1990.

[47] A. Segev, T. Weissbrod and B. Lang, “40 $\mathrm{Ar} /{ }^{39} \mathrm{Ar}$ Dating of the Aptian-Albian Igneous Rocks in Makhtesh Ramon (Negev, Israel) and Its Stratigraphic Implications," Cretaceous Research, Vol. 26, 2005, pp. 633-656. doi:10.1016/j.cretres.2005.03.003

[48] F. Shaaban, R. Lutz, R. Littke, C. Bueker and K. Odisho, "Source-Rock Evaluation and Basin Modelling in NE Egypt (NE Nile Delta and Northern Sinai)," Journal of Petroleum Geology, Vol. 29, No. 2, 2006, pp. 103-124. doi:10.1111/j.1747-5457.2006.00103.x

[49] C. Walley, "Some Outstanding Issues in the Geology of Lebanon and Their Importance in the Tectonic Evolution of the Levantine Region,” Tectonophysics, Vol. 298, 1998, pp. 37-62. doi:10.1016/S0040-1951(98)00177-2

[50] F. Bender, “Geology of Jordan,” Berlin, Gebruder Borntraeger, 1974.

[51] Y. Bartov, "Geological Photomap of Israel and Adjacent Areas, 1:750,000,” The Geological Survey of Israel, Jerusalem, 1974.

[52] B. Lang and G. Steinitz, "K-Ar Dating of Mesozoic Magmatic Rocks in Israel: A Review," Israel Journal of Earth Science, Vol. 38, 1989, pp. 89-103.

[53] G. Shaliv, "Stages in the Tectonics and Volcanic History of the Neogene Basin in the Lower Galilee and the Valleys,” Ph.D. Thesis, Hebrew University, Jerusalem, 1991, p. 94. (in Hebrew, English summary)

[54] Y. Folkman and Z. Yuval, "Aeromagnetic Map of Israel, 1:250,000,” Israel Institute for Petroleum Research and Geophysics, Holon, Israel, 1976.

[55] A. Ginzburg, Y. Folkman, M. Rybakov, Y. Rotstein, Y. Assael and Z. Yuval, "Israel: Bouguer Gravity Map, Scale 1:250,000,” Survey of Israel, Jerusalem, 1993.

[56] M. Rybakov, V. Goldshmidt and Y. Rotstein, "New Compilation of the Gravity and Magnetic Maps of the Levant," Geophysical Research Letters, Vol. 24, 1997, pp. 33-36.

[57] D. T. Sandwell and W. H. F. Smith, "Global Marine Gravity from Retracked Geosat and ERS-1 Altimetry: Ridge Segmentation versus Spreading Rate,” Journal of Geophysical Research, Vol. 114, No. B01411, 2009. 
doi:10.1029/96GL03617

[58] L. V. Eppelbaum and A. N. Pilchin, "Methodology of Curie Discontinuity Map Development for Regions with Low Thermal Characteristics: An Example from Israel,” Earth and Planetary Sciences Letters, Vol. 243, No. 3-4, 2006, pp. 536-551. doi:10.1016/j.epsl.2006.01.003

[59] D. Levitte and A. Olshina, "Isotherm and Geothermal Gradient Maps of Israel,” Geological Survey of Israel, 1985.

[60] A. Shapira and G. Shamir, "Seismicity Parameters of Seismogenic Zones in and around Israel," 1994.

[61] G. Vannucci, S. Pondrelli, A. Argnani, A. Morelli, P. Gasperini and E. Boschi, "An Atlas of Mediterranean Seismicity,” Annals of Geophysics, Vol. 47, No. 1, 2004, pp. 247-306.

[62] Z. Ben-Avraham and A. Ginzburg, "Magnetic Anomalies across the Levant Continental Margin," Marine and Petroleum Geology, Vol. 3, 1986, pp. 220-233. doi:10.1016/0264-8172(86)90046-2

[63] A. N. Pilchin and L. V. Eppelbaum, "Determination of Magnetized Bodies Lower Edges by Using Geothermal Data,” Geophysical Journal International, Vol. 128, No. 1, 1997, pp. 167-174. doi:10.1111/j.1365-246X.1997.tb04077.x

[64] A. Berkovitch, I. Binkin, L. Eppelbaum, N. Scharff and E. Guberman, "Integration of Advanced Multifocusing Seismics with Potential Field Analysis: Heletz Oil Field (Central Israel) Example,” Journal of the Balkan Geophysical Society, Vol. 8, No. (Suppl. 1), 2005, pp. 593596.

[65] L. V. Eppelbaum, "Combined Interpretation of Gravity and Magnetic Fields over the Rosh-Ha'Ayin Structure, Israel," Transactions of the Conference of the Geological Society of America, North-Central Section, Iowa, Vol. 28, No. 6, 1996, p. 38.

[66] L. V. Eppelbaum, M. M. Modelevsky and Pilchin A. N., "Thermal Investigation in Petroleum Geology: The Experience of Implication in the Dead Sea Rift Zone, Israel,” Journal of Petroleum Geology, Vol. 19, No. 4, 1996, pp. 425-444. doi:10.1111/j.1747-5457.1996.tb00448.x

[67] L. V. Eppelbaum, Y. A. Livshits, A. Flexer and Z. BenAvraham, "Integrated Geological-Geophysical Analysis of Ring Structures Phenomenon in the Eastern Mediterranean," Transactions of the Conference of Israel Geological Society, Annual Meeting, Mizpe-Ramon, 1998, p. 25.

[68] L. Eppelbaum, Z. Ben-Avraham and Y. Katz, "Does Mantle Diapir Produce Hebron Magnetic Anomaly?” Transactions of the Conference of Israel Geological Society, Annual Meeting, Moshabim Country Logging (Negev), 2005, p. 26.

[69] L. Eppelbaum, Y. Katz and Z. Ben-Avraham, "Mt. Carmel Structure as a Plate Tectonics Phenomenon,” Transactions of the Conference of the Israel Geological Society, Annual meeting, Beit-Shean, 2006, p. 31.
[70] L. V. Eppelbaum, V. L. Vaksman, S. V. Kouznetsov, L. M. Sazonova, S. A. Smirnov, A. V. Surkov, B. Bezlepkin, Y. Katz, N. N. Korotaeva and G. Belovitskaya, "Discovering of Microdiamonds and Minerals-Satellites in Canyon Makhtesh Ramon (Negev Desert, Israel),” Doklady Earth Sciences (Springer), Vol. 407, No. 2, 2006, pp. 202- 204. doi:10.1134/S1028334X06020097

[71] L. V. Eppelbaum, Z. Ben-Avraham and Y. I. Katz, "Structure of the Sea of Galilee and Kinarot Valley Derived from Combined Geological-Geophysical Analysis," First Break, Vol. 25, No. 1, 2007, pp. 21-28.

[72] A. Ginzburg and L. Eppelbaum, "A Combined 3-D Interpretation of the Carmel Gravity and Magnetic Anomalies," Report Prepared on Behalf of Oilfields Ltd., Israel, 1993.

[73] A. Ginzburg and L. Eppelbaum, “A 3-D Reinterpretation of the Ma'Anit Gravity Anomaly,” Report Prepared on Behalf of Oilfields Ltd., Israel, 1994.

[74] Y. I. Katz and L. V. Eppelbaum, "Preliminary Results of Basin Mapping of the Lower Cretaceous Traps in Northern Israel,” Transactions of the Conference of Israel Geological Society, Annual Meeting, Dead Sea, 1999, p. 40.

[75] Y. I. Katz and L. V. Eppelbaum, "Levantine Phase of Tectonic-Thermal Activity in the Eastern Mediterranean," Transactions of the Annual Meet of Geological Society of American, Section: Planetary Geology, Vol. 31, No. 7, 1999, p. A119.

[76] Z. Ben-Avraham, J. Woodside, E. Lodolo, M. Gardosh, M. Grasso, A. Camerlenghi and G.-B. Vai, "Eastern Mediterranean Basin Systems,” In: D. G. Gee and R. A. Stephenson, Eds., European Lithosphere Dynamics, Geological Society, London, Vol. 32, 2006, pp. 263-276.

[77] A. Segev and M. Rybakov, "Effects of Cretaceous Plume and Convergence, and Early Tertiary Tectonomagmatic quiescence on the Central and Southern Levant Continental Margin,” Journal of the Geological Society, London, Vol. 167, 2010, pp. 731-749. doi:10.1144/0016-76492009-118

[78] M. Rybakov, "What is the Reason for the Dead Sea Transform Fault System Segmentation?” Israel Journal of Earth Science, Vol. 52, 2003, pp. 65-75. doi:10.1560/JNQ0-UWCX-PAVN-XJT7

[79] A. I. Levorsen, "Geology of Petroleum,” Freeman \& Co., San-Francisco/London, 1967.

[80] F. Hirsch and L. Picard, "The Jurassic Facies in the Levant," Journal of Petroleum Geology, Vol. 11, No. 3, 1988, pp. 277-308. doi:10.1111/j.1747-5457.1988.tb00819.x

[81] F. Hirsch, ”Jurassic of Israel," In: J. K. Hall, V. A. Krasheninnikov, F. Hirsch, C. Benjamini and A. Flexer, Eds., Volume II: The Levantine Basin and Israel, Jerusalem, 2005, pp. 361-391.

[82] H. J. Tschopp, “The Oilfield of Heletz, Israel,” Bulletin of Swiss Association on Petroleum, Geology \& Engineering, Vol. 22, No. 63, 1956, pp. 41-54.

[83] Z. Cohen, "Early Cretaceous Buried Canyon: Influence on Accumulation of Hydrocarbons in Heletz Oil Field, Israel,” AAPG Bulletin, Vol. 60, No. 1, 1976, pp. 108- 
114.

[84] L. V. Eppelbaum, "Methodology of 3-D Combined Modeling of Magnetic and Gravity Fields in the Eastern Mediterranean," Proceedings of the $3^{\text {rd }}$ EUG Meeting, Vol. 8, 2006, p. 4.

[85] J. Mascle, J. Benkhelil, G. Bellaiche, T. Zitter and L. Loncke, "Marine Geologic Evidence for a Levantine-Sinai Plate, New Piece of the Mediterranean Puzzle,” Geology, Vol. 28, No. 9, 2000, pp. 779-282.

doi:10.1130/0091-7613(2000)028<0779:MGEFAL $>2.3$. $\mathrm{CO} ; 2$

[86] D. Neev, "The Pelusium Line - A Major Transcontinental Shear," Tectonophysics, Vol. 38, No. 3-4, 1977, pp.
114- 123. doi:10.1016/0040-1951(77)90207-4

[87] M. A. El-Ghamri, I. C. Warburton and S. D. Burley, "Hydrocarbon Generation and Charging in the October Field, Gulf of Suez, Egypt," Journal of Petroleum Geology, Vol. 25, No. 4, 2002, pp. 433-464. doi:10.1111/j.1747-5457.2002.tb00094.x

[88] A. Nissenbaum and M. Goldberg, “Asphalts, Heavy Oils, Ozocerite and Gases in the Dead Sea Basin,” Organic Geochemistry, Vol. 2, No. 3-4, 1980, pp. 167-180. doi:10.1016/0146-6380(80)90007-8

[89] P. R. May, "Oil and Gas Potential of the Galilee, Israel,” Rep. 87/12, Oil Exploration of Israel Ltd, Tel Aviv, 1987, p. 79. 